\title{
Sociocultural Needs of Young People as a Resource for the Formation of National Identity
}

\author{
Tatyana Strunkina $^{1}$, Elena Shmeleva ${ }^{1,}$,, Viacheslav Okeansky ${ }^{1}$, \\ Zhanna Okeansky ${ }^{2}$ and Anzhela Romanova ${ }^{3}$ \\ ${ }_{1}^{1}$ Ivanovo State University, 155908 Kooperativnaya Str., 24, Shuya, Russia \\ ${ }^{2}$ Ivanovo Fire Rescue Academy of Russian Federation for Civil Defense, Emergencies and Elimination of Consequences of Natural \\ Disasters, 153040 Stroiteley Pr., 33, Ivanovo, Russia \\ ${ }^{3}$ Russian State Social University, 107150 Wilhelm Pieck Str., 4, Moscow, Russia
}

\begin{abstract}
The article examines the impact of socio-cultural needs on the formation of national identity of youth. The article presents the results of the study of socio-cultural needs characterizing national citizenship of the Russian youth: the need for preserving the traditions of society, its institutions and values; to follow the norms of morality; belonging to the country and their citizenship, language and traditions; acceptance; to protect the interests of the country and its people; feeling pride for the country; to have freedom of religion; to follow the traditions and norms of the society; to serve for the good of their homeland; for maintaining the familiar way of life; for idealism; for readiness to sacrifice oneself for the sake of others. The authors have concluded that national identity of the Russian youth is formed through awareness of uniting values, that are associated with patriotism, spiritual dimensions of culture, and the formation of personal identity. The content of civil-national identity has been revealed. It includes needs in conservation of society traditions, their institutes and values; in following moral standards; in belonging to the country and citizenship, language and traditions; in protection of the motherland and nation interests; in the necessity to be proud of the one's country.
\end{abstract}

\section{Introduction}

Formation of youth identity, its citizenship and patriotism became one of the main vectors of state policy. Civil identity is formed by concentration at the most important individual's aspirations. It represents the level of public spirit, the unity of government and society. Civil identity is a consolidation factor of the country interest, which shows political and spiritual society wholeness. Civil identity is caused by understanding of the historical commonness of territories, law and institutions, political equality for citizens, trust for political institutions, civil ideology and culture unity, the wish for being a part of the state [1].

The education system plays a vital role in establishing national identity and education of the citizen. Recent studies by Russian sociologists show that the Russian self-consciousness among today's youth is dominant. Approximately $80-95 \%$ of young people polled say they consider themselves Russians and feel their bond with Russia, and 70\% responded that they feel a strong bond with the citizens of Russia [2].

However, in today's socio-cultural practice, the process of formation of the civil consciousness in the

\footnotetext{
a Corresponding author: noc_shmeleva@mail.ru
}

young population is often complicated by the consumer attitudes towards young people's lives; insufficient social protection of young people, as expressed by financial difficulties, domestic order; erosion of traditional moral values; lack of educational, culturally-informing measures for the formation of Russian civil identity [3].

Youth is the most socially active part of the population. Inheriting the degree of social development, the young population forms an image of the future and should be treated as potential for innovation, the role of which must be considered in all aspects of life [4].

The federal target program "Strengthening the unity of the Russian nation and the ethnic and cultural development of the peoples of Russia" all-Russian civil identity education serves one of the objectives of domestic policy of Russia. A key objective of education is increasingly declared; there is a need for actualizing the formation of civil identity of the younger generation. The state program "Patriotic Education of Citizens of the Russian Federation for 2011-2015" includes a set of measures aimed at establishing patriotism as the moral basis for the formation of their active life philosophy.

Ensuring formation of the Russian civil identity of students, mastery of spiritual values and culture of 
Russia; education and socialization of students, their self-identification through personally and socially meaningful activities, social and civil formation, also through the implementation of educational programs, is part of the federal state educational standards. The most important tool for the reproduction and transmission of traditional moral values of the Russian society is the culture. The objectives of the cultural policy of the State include the preservation and support of the cultural traditions that make up an integral part of the national identity of the citizens of the state.

\section{Materials and methods}

As a resource of formation of the national identity of youth, we consider the socio-cultural needs. That is what the youth population is interested in and in need of, it serves as the vector of development, as well as creates the personality forming internal environment.

To study the socio-cultural needs of young people, we have developed a questionnaire containing various descriptions of needs. The survey involved 386 university students of Ivanovo region. Respondents were acquainted with the concept of socio-cultural needs as needs, characterizing the human desire to find a reflection of the culture of society in its being through direct interaction with society. Respondents were asked to select those of the proposed needs, which, in their opinion, can be attributed to socio-cultural needs.

Among the descriptions of needs were proposed needs for preserving the traditions of society, its institutions and values; to follow the norms of morality; for belonging to the country and their citizenship, language and traditions; for social acceptance; to protect the interests of the country and its people; for feeling pride for the country; to have freedom of religion; to follow the traditions and norms of the society; to serve for the good of their homeland; for maintaining the familiar way of life; for idealism; for readiness to sacrifice oneself for the sake of others. These, in our view, can stand for national civil identifiers.

\section{Results and discussion}

An analysis of the results outlined three groups of needs.

The first quarter of the proposed list includes those that have been chosen in more than $64 \%$ of cases; the second quarter - the needs, chosen in $57 \%$ to $63 \%$ of cases; in the second half there were the needs chosen in less than $44 \%$ of cases. In the range between $44 \%$ and $57 \%$ there were needs of other particularity, thereby dividing the needs of the second and third groups. The gathered data can be seen in Table 1 .

Table 1. The results of the study of social and cultural needs of youth

\begin{tabular}{clc}
\hline №. & Socio-cultural needs & $\begin{array}{c}\text { Total amount of } \\
\text { choices, } \%\end{array}$ \\
\hline 1 & $\begin{array}{l}\text { In preserving the traditions } \\
\text { of society, its institutions } \\
\text { and values }\end{array}$ & 68.23 \\
\hline
\end{tabular}

\begin{tabular}{clc}
\hline 2 & $\begin{array}{l}\text { In following the norms of } \\
\text { morality }\end{array}$ & 67.19 \\
\hline 3 & $\begin{array}{l}\text { In belonging to the country } \\
\text { and their nationality, } \\
\text { language, traditions }\end{array}$ & 66.67 \\
\hline 4 & In social acceptance & 65.63 \\
\hline 5 & $\begin{array}{l}\text { To protect the interests of } \\
\text { the Motherland and its } \\
\text { people }\end{array}$ & 64.84 \\
\hline 6 & $\begin{array}{l}\text { The need to feel pride for } \\
\text { their country }\end{array}$ & 64.06 \\
\hline 7 & In religious freedom & 62.5 \\
\hline 8 & $\begin{array}{l}\text { In following the traditions } \\
\text { and norms of society }\end{array}$ & 61.46 \\
\hline 9 & To serve their Motherland & 57.29 \\
\hline 10 & $\begin{array}{l}\text { In the preservation of } \\
\text { livelihoods }\end{array}$ & 39.32 \\
\hline 11 & $\begin{array}{l}\text { In giving of ourselves to } \\
\text { others }\end{array}$ \\
\hline
\end{tabular}

The first group of needs included the needs for preserving the traditions of society, its institutions and values (stated by $68.23 \%$ of respondents), to follow the norms of morality $(67.19 \%)$, belonging to the country and their citizenship, language, traditions (66.67\%), to be socially accepted $(65.63 \%)$, to protect the interests of the country and its people $(64.84 \%)$, and the need to feel pride for the country $(64.06 \%)$. These requirements were noted by respondents as the most important to the culture of the society, affecting all spheres of social interaction of the individual [5]. Young people mostly understand the value of society's traditions, see this cultural heritage in it, except moral norms, and are ready to defend the interests of the country and are proud of it. The unraveled content indicates the desire to be a part of their culture and traditions, patriotism and the desire of young people for national identity. In this case there appear important social needs for the human being, identified in Maslow's theory as the needs for belonging and recognition (self-esteem). These needs are the third and fourth steps of the famous Hierarchy of Needs pyramid, which points to a fairly high level of personal awareness [4]. People that possess needs of this rank do not experience physiological discomfort and feel safe.

The second group included the need for freedom of religion $(62.5 \%)$, to follow the traditions and norms of society $(61.46 \%)$, to serve for the benefit of their homeland $(57.29 \%)$. Selection of these items takes the middle position in the overall ranking of our research, as if to show us the oscillation of modern youth's attitudes towards them. Probably, the respondents see the difficulties of modern society in following the traditions, keeping freedom of religion and striving to serve the Motherland. Slightly more than a half of the respondents acknowledge these as socio-cultural needs, accrediting them with meaningful, valuable to the culture of society. That is, $37.5 \%$ of respondents do not consider religious freedom to be a manifestation of the culture of society. Perhaps they encountered acts of aggression against the freedom of religion or do not consider it a public matter. $38.54 \%$ of the interviewed young people do not accept the traditions of the society, as a cultural phenomenon, and $42.71 \%$ - do not consider service to the motherland 
as a socio-cultural need, do not view it as a reflection of the culture, and probably, do not consider such a need to be inherent in this particular society.

The third group consisted of needs for maintaining a familiar way of life (43.49\%), for idealism (39.32\%), and for sacrificing oneself for the sake of other people $(38.54 \%)$. The manifestations of the 90 s crisis, certainly left a mark on the spiritual and moral state of society. Change in the familiar political system reflected in the transformation of ideals, blurring the laws of morality. Collectivism was replaced by individualism [6]. People have lost their sense of unity and teamwork. A new generation has grown on this foundation. Perhaps these factors contribute to the fact that in a modern society most young people do not find any need to maintain a habitual way of life, to have an ideal, or to be altruistic.
The next research step is supposed to study the level of socio-cultural needs evident to students. Students were to rate the evidence level using five-point scale 1 absent, 2 - more likely absent, 3 - more likely present, 4 rather present, 5 - pronounced.

A statistic-mathematician result revealed that respondent's opinion is sufficiently uniform. It can be proved by small variations of asymmetry indexes $(A s)$ which from 0 exceeds $(E x)$ among the majority of indexes.

The option uniformity among students proves variations coefficient $(V)$ which is from $17 \%$ to $36 \%$, it means that average value $(V)$ is typical, while the group under investigation is uniform.

Table 2. Mathematician-statistical processing of the of results of research of socio-cultural needs of students $(n=341)$

\begin{tabular}{|c|c|c|c|c|c|c|c|c|c|}
\hline № & The socio-cultural needs & $\mathrm{X}$ & $\mathrm{M}$ & $\mathrm{Me}$ & Mo & $\sigma$ & Ex & As & $\mathrm{V}(\%)$ \\
\hline 1 & $\begin{array}{l}\text { In traditions conservation, their } \\
\text { institutes and values }\end{array}$ & 3.54 & 0.054 & 4 & 4 & 1.00 & 0.17 & -0.55 & $28 \%$ \\
\hline 2 & In following moral standards & 3.78 & 0.049 & 4 & 4 & 0.91 & 0.50 & -0.65 & $24 \%$ \\
\hline 3 & $\begin{array}{l}\text { In belonging to country and } \\
\text { citizenship, language and } \\
\text { traditions }\end{array}$ & 3.93 & 0.053 & 4 & 4 & 0.97 & 0.72 & -0.89 & $25 \%$ \\
\hline 4 & $\begin{array}{l}\text { In protection of the motherland } \\
\text { and nation interests }\end{array}$ & 3.74 & 0.053 & 4 & 4 & 0.98 & 0.15 & -0.58 & $26 \%$ \\
\hline 5 & $\begin{array}{l}\text { In need to be proud of one's } \\
\text { country }\end{array}$ & 3.91 & 0.054 & 4 & 4 & 0.99 & 0.48 & -0.84 & $25 \%$ \\
\hline 6 & In religion freedom & 3.58 & 0.060 & 4 & 4 & 1.11 & -0.16 & -0.60 & $31 \%$ \\
\hline 7 & In society acceptance & 3.64 & 0.053 & 4 & 4 & 0.97 & 0.29 & -0.62 & $27 \%$ \\
\hline
\end{tabular}

All noted socio-cultural values were referred to a "more likely present" category: conservation of traditions, institutes and values $(X=3.54 \pm 0.054)$; following moral standards $(X=3.78 \pm 0.049)$; belonging to the country and citizenship, language and traditions $(X=3.93 \pm 0.053)$; protection of the motherland and national interests $(X=3.74 \pm 0.053)$; need to be proud of the one's country $(X=3.91 \pm 0.053)$; social acceptance $(X=3.64 \pm 0.053)$; religion freedom $(X=3.58 \pm 0.060)$.

Students might have not decided yet whether they have the listed needs or not. It may be connected with age-related world-view features, which are not ready for listed needs satisfactions, but still measure their value in future. That is the reason why highly developed patriotic feeling assumption was premature. Due to factor analysis, a structure of socio-cultural needs defining factors was discovered. The nation-civil identity factor is shown in figure 1 .

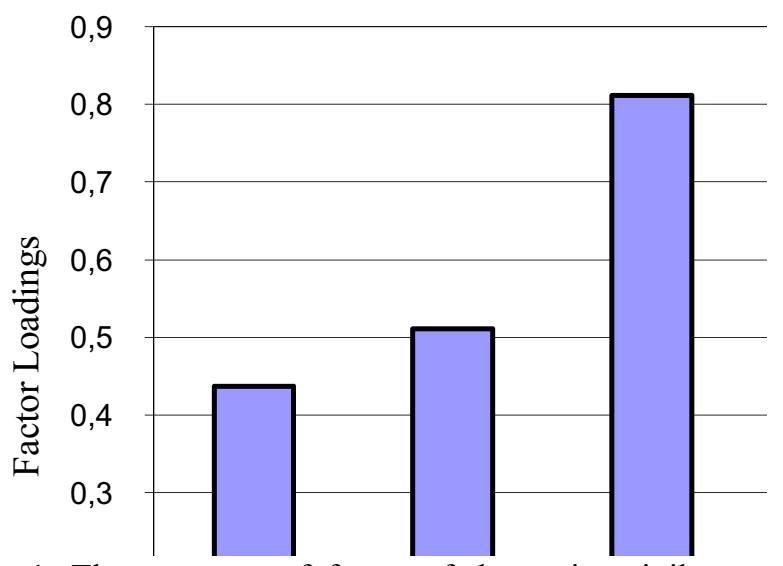

Figure 1. The structure of factor of the nation-civil identity

Note: 1 - traditions conservation, their institutes and values; 2 - following moral standards; 3 - belonging to country and citizenship, language and traditions; 4 protection of the motherland and nation interests; 5 need to be proud of one's country. 
A "nation-civil identity" factor is the most valuable one among other socio-cultural student's needs 28.434 , which makes $50.5 \%$ of the overall sociocultural needs factor system. It shows patriotic attitude to the country (need in being proud of the country) willingness to conserve culture (traditions, their institutes and values; following moral standards) protecting citizenship status (belonging to the country and citizenship, language and traditions, protecting the motherland and nation interests).

National-civil identity takes a central place in the structural-content modal system of socio-cultural needs. It represents the core of the model. The core contributes to the listed needs development among students; it helps them to identify themselves like a citizen, expressing patriotic feelings and willingness to pass it to the next generations.

Nation-civil identity needs are represented by national recognition, patriotic feelings, understanding of main country problems and responsibility for the country future. This kind of youth has citizen and political reference points; they are in a patriotic mood.

\section{Conclusion}

Thus, we see that the modern Russian student-age population experiences the cultural concern about needs for tradition, patriotism, but experiences difficulties in the search for an ideal. New ideals are not yet a part of the youth's mindset, but there is a tendency of preservation and support of cultural traditions that make up an important part of the national identity of the citizens of the state. It can be noted that the formation of civil identity of Russian youth is characterized by the knowledge of the existence of uniting values, based on the principles of patriotism, spirituality, culture; formation of personality with social maturity.

Due to factor analysis, a structure of nation-civil identity has been discovered. It includes needs in conservation society traditions, their institutes and values; following moral standards; belonging to the country, citizenship, language and traditions; protecting the motherland and national interests; being proud of the country. Nation-civil identity is the basement of socio-cultural needs.

It should be noted that an important factor in the youth's awareness of the state's culture is the ongoing establishment of a new state policy of Russia, where we are talking about a special Russian civilization [7; 8]. This is evidenced by the foundations of the government's cultural policy adopted in 2014, which replaced the basic legislation on culture in 1992.

Further investigation will allow us to reveal whether or not national identity is a factor in the socio-cultural system of needs of young people, and to develop programs intended to form it in a student environment [9].

Nation-state identity is the factor of the sociocultural system of youth's needs. The government politics dictates the necessity of programming its development in students' sphere. Systematic support of programs and projects aimed at forming an active citizenship of young people, a national identity, the preservation of moral values, and prevention of extremism, will strengthen all-Russian civil self-consciousness [10].

\section{References}

1. A.G. Sanina, Sociological researches, 3, 77-87 (2012)

2. M. J. Martynova, Bulletin of the Russian nation, 2, 173 - 195 (2014)

3. P.A. Kislyakov, E.A. Shmeleva, T.V. Karaseva, O.A. Silaeva, Asian Social Science, 10 (17), 285 292 (2014)

4. A. Maslow, Motivation and personality (SPb.: Peter, 2006)

5. A.V. Golovashina Sociological researches, 7 (375), 64-71 (2015)

6. The people of Russia. The history and meaning of national identity (M.: Nauka, 2013)

7. V.P. Okeansky Philosophy of economy: Almanac Center of Social Sciences and the Faculty of Economics of Moscow State University, 5 (83), 283-284 (2012)

8. V.P. Okeansky, Zh. L. Okeansky, News of higher educational institutions. Series "Humanities", 4 (2), 149-153 (2013)

9. E.A. Shmeleva, Kislyakov P.A. , L.F. Luneva, L.D. Maltseva, Psychology in Russia: State of the Art, 8(1), 74-85 (2015)

10. The program of psycho-pedagogical training of parents on the formation of civil identity in the framework of social partnership of family and school (Moscow, 2012) 